\title{
DOES THE NUMBER OF SUPERVISED COUNSELING PRACTICE EXPERIENCES MAKE DIFFERENCE IN THE WISDOM OF PRE-SERVICE COUNSELORS?
}

\author{
Agus Taufiq ${ }^{1 *}$, Herdi Herdi ${ }^{1,2}$ \\ ${ }^{1}$ Universitas Pendidikan Indonesia, Indonesia \\ ${ }^{2}$ Universitas Negeri Jakarta, Indonesia \\ *e-mail: afiq@upi.edu
}

\begin{abstract}
Wisdom is one of the fundamental qualities of personality, core competence, and predictors of effective counselor. The wisdom of a pre-service counselor is predicted to develop if the counselor has the opportunity to undergo, ask, reflect, and internalize his/her experiences through supervised counseling practice. The objective of the research is to compare the wisdom resulted by Indonesian pre-service counselors based on the number of supervision during counseling practices. The research used the ex post facto method. The sample of this research consisted of 489 sixth semester pre-service counselors of 11 guidance and counseling department in Indonesia, whereas 307 students only received $<3 \mathrm{x}$ supervision, and 182 students with $>3 x$ supervision. Data were collected using Indonesian Counselor's Wisdom Scale with Cronbach's Alpha $=.92$. The t-test results show that there was a significant difference in the average score of wisdom and each dimension: religious, personal, social, emotional, reflective, and ethic of the pre-service counselors based on the number of supervised counseling practice where those with less supervision had better quality of wisdom. This means that the small number of supervised counseling practice experience but with a quality of supervisory working alliance can develop the wisdom of pre-service counselors.
\end{abstract}

Keywords: counseling, counselor education and supervision, wisdom

\section{APAKAH JUMLAH PENGALAMAN PRAKTIK KONSELING TERSUPERVISI DAPAT MEMBEDAKAN KEARIFAN CALON KONSELOR?}

\begin{abstract}
Abstrak: Kearifan merupakan salah satu kualitas fundamental kepribadian, kompetensi inti, dan prediktor konselor yang efektif. Kearifan calon konselor diprediksi dapat dikembangkan jika diberi kesempatan untuk mengalami, bertanya, merefleksi, dan menginternalisasi pengalamannya melalui praktik konseling tersupervisi. Tujuan penelitian ini adalah untuk membandingkan kearifan calon konselor Indonesia berdasarkan pengalaman praktik konseling tersupervisi. Penelitian menggunakan metode ex post facto. Sampel penelitian terdiri atas 307 calon konselor yang dengan frekuensi praktik konseling tersupervisi $\leq 3 x$ dan 182 calon konselor $>3 x$ dari 11 Program Studi Bimbingan dan Konseling di Indonesia. Data penelitian dikumpulkan menggunakan Skala Kearifan Konselor Indonesia dengan Alpha Cronbach $=.92$. Data dianalisis menggunakan independent sample t-test. Hasil penelitian menunjukkan bahwa terdapat perbedaan yang signifikan skor rata-rata kearifan calon konselor, baik secara keseluruhan maupun dimensi religius, pribadi, sosial, emosional, reflektif, dan etik pada calon konselor berdasarkan jumlah praktik konseling tersupervisi dimana supervisi yang sedikit memiliki kearifan yang lebih baik. Ini berarti bahwa jumlah pengalaman praktik konseling tersupervisi yang sedikit namun dengan aliansi kerja supervisi yang berkualitas dapat mengembangkan kearifan calon konselor.
\end{abstract}

\section{Kata Kunci: kearifan, konseling, pendidikan dan supervisi konselor}

\section{INTRODUCTION}

The issue of wisdom of pre-service counselors is interesting and important. It is interesting because wisdom is usually associated with the characteristics of counselors who are already senior in terms of experience and age. It is important because wisdom becomes a new paradigm, aim of education, and plays an important role in counseling for counselors, but tend to be neglected in education, both elementary and secondary education (Bruya \& Ardelt, 2018; Sternberg \& Hagen, 2019), higher education (Ardelt, 2018), including counselor education and supervision program (Hanna, 
Bemak, \& Chung, 1999; Osterlund, 2014; Levitt \& Piazza-Bonin, 2016).

Wisdom is the virtue of successfully facing the final stage of psychosocial crisis (integrity versus despair) in old age (Erikson, 1959). Other studies find that wisdom is positively correlated with quality of life for individuals and multicultural communities, such as mental health (Webster, Westerhof, \& Bohlmeijer, 2014), psychological well-being (Zacher \& Staudinger, 2018), coping strategies, selfcontrol, and positive involvement of life for a happy life (Etezadi \& Pushkar, 2013), health, hope, self-esteem, positive feelings, humility, social relations, and life satisfaction (Krause, 2016). In essence, wisdom can guide individuals to transform life and to live right and better life (Yang, 2013).

Research on wisdom has been more concerned with the characteristics of a wise person, the factors that affect wisdom, and the measurement of wisdom. There has been no research that specifically examines the differences in the wisdom of pre-service counselors based on their supervised counseling practice experiences by supervisor or counselor educator in counselor education programs. Phan, Torres-Rivera, Volker, \& Maddux (2009) indicated that $14 \%$ of the competence of counseling is influenced by the wisdom of the counselor him/herself. Conversely, the absence of wisdom makes the counselors trapped into the behavior of "foolishness" (Aczel, 2019), which can endanger, inhibit, and even lead to failure of the relationship and outcomes of counseling.

Wisdom can be developed (such as Kunzmann \& Baltes, 2005) through various facilitating factors. They identified three factors that influence the development of wisdom, which are: contextual, expertise, and personal factors. Among the factors that influence the development of wisdom is professional experience, professional education and training, and experience of ongoing practices (Glück, König, Naschenweng, Redzanowski, Dorner, Straßer, \& Wiedermann, 2013; Levitt \& Piazza-Bonin, 2017). The development of wisdom requires transcendence and projection that can be gained through self-awareness, self-examination, and reflection on behavior, interactions, and experiences throughout the life span. While (Frantz, 2014) found key factors influencing the development of wisdom, namely learning from experience through reflection, integration, and experience transformation. The professional experience of pre-service counselors can be obtained through a number of supervised counseling practice experiences from counselor educators.

In counselor education programs, supervision is a vital component, fundamental intervention, and instrumental pedagogy for the education (Bernard \& Goodyear, 2014). It also occupies a central role in personal and professional development of counselors. Counselor education programs need to reflect on standards that emphasize the importance of supervising the development of counselor candidate competencies through relevant individual, triadic, and group (CACREP, 2016; ACES, 2011). The experience of getting good supervision in the internship program has a significant impact on the performance of counselor.

For a pre-service counselor, the experience of practicum in counseling is supervised by a counselor educator. Supervised counseling practices are essential to protect clients from preservice counselors' improper treatment on the one hand, and to assist the pre-service counselors in developing their professional competence on the other hand (Bernard \& Goodyear, 2014). Supervision of counseling practices in the location where professional practices take place is an inherent and vital aspect of the professional education of the counselors.

Bernard \& Goodyear (2014) argued that supervisors should engage in effective professional interventions in the pre-service counselors' process of achieving personal and professional competence. In this context, the supervisor must perform the function of a clinical supervisor and serve as a trainer, instructor, mentor, administrator, and assessor of the professional competence to be mastered by a pre-service counselor. There are several research findings on the evaluation of supervision, one of which indicated that counselors' confidence and work beliefs are correlated to the quality and quantity of feedback provided by the supervisor (Bernard \& Goodyear, 2014). They found that the number of supervisory skills is a high variable and is associated with low conflicts between supervisors and supervised counselors.

Does The Number of Supervised Counseling Practice Experiences Make Difference in The Wisdom of Pre-Service Counselors? 
Additionally, they demonstrated that selfawareness and professional behaviors targeted by counseling interventions are closely related to the frequencies of clear, consistent, measurable, achievable, realistic, and timely feedback.

Supervision in counselor education programs is one of the key factors influencing the development of personal and professional competency of the counselor's candidates. The maingoals of counselor education and supervision are to educate and to train the candidates in developing counseling competencies and to enrich their professional experience (Bernard \& Goodyear, 2014; CACREP, 2016; McAuliffe $\&$ Eriksen, 2011), also their self-awareness and reflective practice (Granello \& Young, 2012). Previous studies reveal that education and training could increase the candidates' selfefficacy in counseling.

The number of supervised counseling practice experiences can influence the development of pre-service counselor's wisdom (Levitt \& Piazza-Bonin, 2017; Osterlund, 2016). Supervisory working alliances in the first few sessions constitute a "window of opportunity" to supervision processes and outcomes (Bordin, 1983). If the supervisee judges that the supervisory working alliance is well established during the beginning of the sessions (usually the third session), it tends to give a positive impact on supervision outcomes (Bordin, 1983; Fluckiger, Del Re, Wampold, \& Horvath, 2018; Crits-Christoph, Gibbons, \& Mukherjee, 2013). Conversely, supervision that is too often but less effective will make supervised become dependent, feel bored, and make the supervision relationship ineffective and adversely affect the process and the output of supervision (Ladany, Mori, \& Mehr, 2013).

Although, theoretically and empirically, supervision becomes a crucial component in counselor education programs, supervision has not been implemented optimally. Based on this rational, this research thus is focused on examining the differences in the wisdom of Indonesian pre-service counselors based on the number of their supervised counseling practice experiences by counselor educators. This study also aims to examine the differences in seven dimensions of wisdom, namely religious, cognitive, personal, social, emotional, reflective, and ethical Indonesian pre-service counselors based on the number of supervised counseling practice experiences. This research is important as the empirical basis for the development of the wisdom of the pre-service counselors in the counselor education and supervision programs.

\section{METHOD}

The research employed the ex post facto method because it examined the conditions that have been formed, not a result of intervention (Heppner, Wampold, \& Kivlighan, 2008). In this research, ex post facto design was used to compare the wisdom of Indonesian pre-service counselors based on their numbers of supervised counseling practice experiences of less than three times $(\leq 3 \mathrm{x})$ and those with more than three times $(>3 x)$ by counselor educators.

The research sample was selected using the two stage random sampling. There were 489 sixth semester pre-service counselors from 11 guidance and counseling department in Indonesia. More specifically, the numbers of preservice counselors with supervised counseling practice experiences $\leq 3 \mathrm{x}$ and $>3 \mathrm{x}$ were 307 (62.8\%) and $182(37.2 \%)$, respectively.

The 11 guidance and counseling department are mandated to organize counselor education program by the Ministry of Research, Technology, and Higher Education. The 11 guidance and counseling study programs also share similarities in their curriculum, especially the nationally agreed curriculum. The curriculum structure generally covers: general courses, basic education courses, field of expertise and supporting courses, and instructional courses. The curriculum structure is aimed at achieving the nationally determined competence of graduates in accordance with the Decree of the Minister of National Education No. 27 of 2008 on Academic Qualification Standards and Counselor Competences. All of the counselor education institutions require counseling practices to be supervised by both professional counselors and counselor educators.

This research used a 5 Likert scale namely Indonesian Counselor's Wisdom Scale (ICWS). This scale was developed based on the results of meta-analysis on various theories of wisdom (Jeste, Ardelt, Blazer, Kraemer, Vaillant, \& Meeks, 2010; Ardelt, Pridgen, \& Nutter-Pridgen, 2019; Webster, 2019). It's consists of 190 items that are used to measure seven dimensions of 
wisdom, namely: religious (16 items), cognitive (33 items), personal (14 items), social (31 items), emotional (10 items), reflective (21 items), and ethical (12 items). ICWS is a 5-level Likert scale, ranging from $1=$ very inappropriate up to $5=$ very appropriate. The test results using Rasch Model v. 3.73 shows that all items are fit because they meet the criteria for Infit Mnsq, Outfit Mnsq, and Pt-M Corr, the unidimensionality with the Principle Component Analysis (PCA) is 30.2\%, and the Cronbach's Alpha coefficient for test, participants, and items reliability is excellent (.92, .91, and .99) (Linacre, 2019).

The data collection was done using the traditional paper and pencil questionnaire distributed directly to the sixth semester pre-service counselors in 11 guidance and counseling department in Indonesia on an agreed schedule. The pre-service counselors were asked to respond to any statement that suits their condition by choosing one of the alternative answers provided. After the data were collected, the next step was verifying, processing, and analyzing them using t-test. Data were processed using IBM SPSS software v. 25.0.=

\section{RESULTS AND DISCUSSION Results}

The hypothesis of this research is: there is a difference in the average scores of wisdom between the pre-service counselors with supervised counseling practice experiences of $\leq 3 \mathrm{x}$ and $>3 \mathrm{x}$. The statistical results of data analysis are presented in Table 1.

The results of the research as shown in Table 1 indicated that there was a significant difference in the mean scores of wisdom between the pre-service counselors with supervised counseling practice experiences of $\leq 3 \mathrm{x}$ and $>$ $3 \mathrm{x}$. This difference is indicated by the Sig. value $(2$-tailed $)<p(.05)($ Sig. $=.002)$. The frequency of supervised practice counseling experiences has an effect size on wisdom in the medium category.

Table 1 shows: First, there was a significant difference in the mean scores of religious dimension between the pre-service counselors with supervised counseling practice experiences of $\leq 3 \mathrm{x}$ and $>3 \mathrm{x}($ Sig. $=.035)$. The number of supervised practice counseling experiences has an effect size on religious dimension in the small category. Secondly, there was no significant difference in the mean scores of the cognitive dimension of the pre-service counselors with supervised counseling practice experiences of $\leq 3 \mathrm{x}$ and $>3 \mathrm{x}($ Sig. $=.941)$. The number of supervised practice counseling experiences has an effect size on cognitive dimension in the small category. Thirdly, there was no significant difference in the mean personal dimension scores of the pre-service counselors with supervised counseling practice experiences of $\leq 3 \mathrm{x}$ and $>3 \mathrm{x}$ $($ Sig. $=.073)$. The number of supervised practice counseling experiences has an effect size on personal dimension in the small category.

Table 1. Mean, SD, t-test, Sig., and Cohen's d of Wisdom of Pre-Services Counselors Based on Their Frequency of Supervised Counseling Practice Experiences

\begin{tabular}{|c|c|c|c|c|c|c|c|}
\hline \multirow{3}{*}{$\begin{array}{l}\text { Variable/ } \\
\text { Dimension }\end{array}$} & \multicolumn{4}{|c|}{ Supervised Frequencies } & \multirow{3}{*}{$t$} & \multirow{3}{*}{ Sig. } & \multirow[t]{3}{*}{ Cohen's d } \\
\hline & \multicolumn{2}{|c|}{$\leq \mathbf{3 x}$} & \multicolumn{2}{|c|}{$>3 \mathbf{x}$} & & & \\
\hline & $\mathbf{M}$ & SD & $\mathbf{M}$ & SD & & & \\
\hline Wisdom & 495.4 & 44.6 & 481.9 & 48.0 & 3.080 & $.002 *$ & .29 \\
\hline Religious & 55.7 & 10.5 & 53.7 & 9.8 & 2.110 & $.035^{*}$ & .20 \\
\hline Cognitive & 114.1 & 12.7 & 114.2 & 12.8 & -.075 & .941 & -.01 \\
\hline Personal & 50.8 & 6.3 & 49.7 & 6.9 & 1.798 & .073 & .17 \\
\hline Social & 118.0 & 12.6 & 113.1 & 13.5 & 4.060 & $.000^{*}$ & .38 \\
\hline Emotional & 34.3 & 4.3 & 33.3 & 4.1 & 2.605 & $.009^{*}$ & .24 \\
\hline Reflective & 76.2 & 9.0 & 73.8 & 9.0 & 2.813 & $.005^{*}$ & .27 \\
\hline Ethical & 46.4 & 5.9 & 44.2 & 6.4 & 3.809 & $.000^{*}$ & .36 \\
\hline
\end{tabular}

${ }^{*}$ Sig. $<.05$ 
Fourthly, there was a significant difference in the mean scores of social dimension between the pre-service counselors with supervised counseling practice experiences of $\leq 3 \mathrm{x}$ and $>3 \mathrm{x}$ $($ Sig. $=.000)$. The number of supervised practice counseling experiences has an effect size on social dimension in the medium category. Fifthly, there was a significant difference in the mean scores of emotional dimension of the pre-service counselors with supervised counseling practice experiences of $\leq 3 \mathrm{x}$ and $>3 \mathrm{x}$ ( Sig. $=.009)$. The number of supervised practice counseling experiences has an effect size on emotional dimension in the medium category.

Sixthly, there was a significant difference in the reflective dimension of the pre-service counselors with supervised counseling practice experiences of $\leq 3 \mathrm{x}$ and $>3 \mathrm{x}($ Sig. $=.005)$. The number of supervised practice counseling experiences has an effect size on reflective dimension in the medium category. Seventhly, there was a significant difference in the mean scores of ethical dimension of the pre-service counselors with supervised counseling practice experiences of $\leq 3 \mathrm{x}$ and $>3 \mathrm{x}($ Sig. $=.000)$. The frequency of supervised practice counseling experiences has an effect size on ethical dimension in the medium category.

\section{Discussion}

The results showed that there was a difference in the average scores of Indonesian counselors' wisdom based on the number of supervised counseling practice experiences by counselor educators in counselor education programs. The effect size of the number of supervised counseling practice experiences on wisdom, and social, emotional, reflective, and ethical dimensions are in the medium category (Cohen, 1988). It means that the number supervised counseling practice experience proves to be one of the important efforts undertaken to influence the development wisdom of pre-service counselors (Hanna et al., 1999; Levitt \& Piazza-Bonin, 2016; 2017; Osterlund, 2016). Other experts argue that supervision is a instrumental pedagogy suggestions for helping pre-service counselors learn how to reflect on and self-direct their learning (Bernard \& Goodyear, 2014; Borders, 2019). Reflection on the lessons of history may help to recognize some problems with an uncritical faith in the personal qualities of mental health practitioners.

Furthermore, the results of this research support experts' opinion in the Berlin Wisdom Paradigm and previous research findings that among the factors that influence the development of wisdom are professional education and training and continuous practicing professional experience (Baltes, Glück, \& Kunzmann, 2005). Hanna et al., (1999) suggested that to be a wise counselor, pre-service counselors should be given the opportunity to reflect, ask, internalize, and integrate their professional experiences, in this case counseling practice. The development of wisdom requires transcendence and projection that can be gained through self-awareness, self-examination, and reflection on behavior, interactions, and experiences throughout the life span.

This study relevant with Brown's Wisdom Development Theory (2004) that the key factors influencing the development of wisdom, namely learning from professional practice experiences through reflection, integration, and experience transformation. The reflection model that is predicted to be appropriate to develop the wisdom of pre-service counselors is the reflective practitioner (Schoon, 1987) with a model of clinical supervision. It is further argued that reflective practice is aptly used in professional and complex activities, especially nursing and education to cope with various unstructured and unpredictable situations based on similar experiences previously undergone. In EvidenceBased Practice Clinical Supervision, Milne and Reiser (2012: 143) argue that it provides guidelines on what works in terms of practices likely to be effective, and this provides a form of protection from legal and other challenges to one's professional competence."

Moon (2004) argue that the reflective practitioner model will produce such learning outcomes as: (1) knowledge and understanding; (2) some forms of action; (3) critical review process; (4) decision making or the solution to uncertain and unpredictable problems; (5) building theory based on practical experience; (6) creativity; (7) self-empowerment; and (8) clarification and recognition for further reflection. The application of reflective practice to develop the wisdom of pre-service counselors in counselor education programs can be done 
in stages or gradually, ranging from descriptive writing, descriptive reflection, dialogical reflection, and critical reflection (Moon, 2004). The findings of this study are also similar to those of Phan et al. (2009) which show that the learning model of wisdom can be more effective if accompanied by reflection in the supervision process by supervisors or counselor educators.

In counselor education programs, supervision is a vital component, fundamental intervention, and instrumental pedagogy for the education (Bernard \& Goodyear, 2014). Meta-analysis study shown that supervision therefore has a crucial and essential role in the learning and developing of integration skills in students and traines (Tan, 2017). It also occupies a central role in personal and professional development of counselors. Counselor education programs need to reflect on standards that emphasize the importance of supervising the development of counselor candidate competencies through relevant individual, triadic, and group (CACREP, 2016; ACES, 2011). The experience of getting good supervision in the internship program has a significant impact on the performance of counselor.

This research also support previous studies that the number of supervised counseling practice experiences can influence the development of pre-service counselor's wisdom (Osterlund, 2016; Levitt \& Piazza-Bonin, 2017). Supervisory working alliances in the first few sessions constitute a "window of opportunity" to supervision processes and outcomes (Bordin, 1983). If the supervisee judges that the supervisory working alliance is well established during the beginning of the sessions (usually the third session), it tends to give a positive impact on supervision outcomes (Crits-Christoph et al., 2013; Fluckiger et al., 2018).

On the other hand, the small effect size of supervised counseling practice experiences on the religious, cognitive, and personal dimensions is predicted to be influenced by other wisdom determinants. For example, the religious dimension of wisdom can be developed through gradual spiritual guidance, such as the Sufism and meditation tradition. The cognitive dimension of wisdom can be developed through lectures with the Socratic dialogue method (Hanna et al., 1999) and read classic philosophy books (Sternberg, 2013).

The difference in the wisdom profile of the pre-service counselors lies in the following. First, the wisdom profile of the pre-service counselors with supervised counseling practice experiences of $\leq 3 \mathrm{x}$ was in the medium category, supported by five of the seven dimensions: emotional, cognitive, religious, reflective, and personal. Meanwhile, the wisdom of the preservice counselors with experience of supervised counseling practice experiences $>3 \mathrm{x}$ was also in the medium category, but it was supported by six dimensions, namely: emotional, cognitive, religious, reflective, social, and personal dimensions. Secondly, the wisdom of the preservice counselors with supervised counseling practice experiences $\leq 3 \mathrm{x}$ tended to be high and significantly different in social dimension. Meanwhile, the wisdom of the pre-service counselors with supervised practice experiences $>3 \mathrm{x}$ tended to be high and significantly different in the ethical dimension.

The social dimension of wisdom. Social dimension is one of the essential components of wisdom. This is consistent with the opinion of experts and the findings of previous research which show that the social dimension of wisdom includes: pro-social attitudes and behavior and value relativism/tolerance (Meeks \& Jeste, 2009), affective and conscious dimensions of empathy and concern (Hanna \& Ottens, 1995; Hanna et al., 1999), encouragement to achieve public welfare by helping others and contributing to society (Yang, 2013), affective dimension (Ardelt 2011), and dimension of value relativism/tolerance (Baltes et al., 2005).

In this research, the social dimension of wisdom is defined as the ability of pre-service counselors to interact effectively and productively with the counselee. This means that a pre-service counselor with a high social dimension is able to interact effectively and productively with the counselee and others. The dimension of social skills includes: empathic, pro-social, respectful, friendly, caring, unconditional positive regard, guiding, communicative, forgiving, and leadership traits (such as Meeks \& Jeste, 2009).

Pre-service counselors with high empathy tend to be able to take perspective, show empathetic care, and behave appropriately according to a counselee's condition. Preservice counselors with high pro-social attitude

Does The Number of Supervised Counseling Practice Experiences Make Difference in The Wisdom of Pre-Service Counselors? 
tend to be always willing to help a counselee unconditionally. They can appreciate the counselee as a dignified person. They are always friendly, always willing to say hello and greet the counselee first by showing a pleasant facial expression. They will also have a high concern for the counselee's welfare, environment, and life. Such pre-service counselors are also able to accept the counselee the way s/he is and maintain a warm interaction with the counselee (such as Meeks \& Jeste, 2009).

In addition, pre-service counselors with high empathy are able to inspire, model, encourage, and direct a counselee to change his or her behaviors in a positive direction. They are able to establish verbal and non-verbal communication effectively with the counselee. They are also able to always forgive themselves, their counselees, and counseling situations. Finally, pre-service counselors as a leader have leadership qualities to empower the potential of each counselee and manage group dynamics effectively to achieve counseling goals.

The ethical dimension of wisdom. Wisdom is always associated with good, right, and proper behavior, both for oneself and others. Therefore, ethics is one of the essential dimensions of wisdom. This is in line with the opinions of experts and findings of previous research which reveal that wisdom includes the dimensions of: ethical behavior (Descartes in Osbeck \& Robinson, 2005; Jeste et al., 2010).

In this research, it was found that the ethical dimension was in the high category, especially for the pre-service counselors with supervised counseling practice experiences of $>3 x$. Preservice counselors with high ethical dimension of wisdom are characterized by the ability to understand and adhere to the code of ethics of a counselor and to present themselves as a person who is trustworthy, honest, fair, and responsible for the welfare of the counselee. The ability to understand and adhere to the code of ethics is the ability to clearly understand the code of ethics of a counselor and try to obey it when conducting counseling; the pre-service counselor can be trusted by keeping promise and the counselee's secrets. Honest pre-service counselors tend to be able to always express the true thoughts, feelings and behaviors, whatever the risks are. Just pre-service counselors are always willing to give equal opportunity and treatment to each counselee. Finally, just pre-service counselors are able to always take responsibility and be willing to accept the risks of choices and actions regarding themselves and their counselees (Durodoye, 2013).

Wisdom and adherence to the ethical principles possessed and displayed by counselor are a vital and fundamental component in effective multicultural counseling (Durodoye, 2013). Multicultural counselors are expected and required to adhere to ethical principles and have ethical virtues of multicultural counseling. Adherence to ethical principles can guide counselors in dealing with ethical dilemmas, overcoming complex problems, choosing alternatives, making the best decisions, behaving properly and correctly, and overcoming conflicts of interest either intrapersonal, interpersonal, and extrapersonal between themselves and counselees in a variety of multicultural situations effectively. Adherence to principles, virtues, and counseling codes of ethics can protect counselees and users of counseling services. It is also an confirmation of the counselor's professionalism.

The emotional dimension of wisdom. The emotional dimension is also one of the main dimensions of wisdom. This is consistent with the opinion of the expert and results of previous research findings which demonstrate that one of the dimensions of wisdom is affective dimension (Ardelt et al., 2019), emotional management (Brugman, 2006), affective dimension and consciousness (Hanna et al., 1999), emotional balance (Meeks \& Jeste, 2009), emotional skills (Osterlund, 2014), and emotion regulation (Webster, 2019).

The emotional dimension of wisdom is the ability of a counselor to understand, accept, use, and manage the emotions of her/himself and the counselee's to remain calm and patient in dealing with counselees, problems, and counseling situations. Pre-service counselors with emotional dimension of wisdom in the medium category are characterized by being: (1) quite able to recognize and understand the emotional state of themselves and counselee's accurately in certain situations; (2) quite open and sometimes able to accept the emotional state of themselves and counselee's in certain situations; (3) quite able to use the emotional state of themselves and counselee's in making decisions; and (4) quite able to manage the emotions of themselves 
and counselee's so as to remain calm and patient in dealing with counselees, problems, and counseling situations (Mayer, Salovey, \& Caruso, 2004; Muller-Merbach, 2010).

The cognitive dimension of wisdom. The cognitive dimension is one of the main dimensions of wisdom. This is in accordance with the opinions of experts and results of previous research findings that one of the dimensions of wisdom is: cognitive dimension (Hanna \& Ottens, 1995), meta-cognitive skills (Brugman, 2006), and cognitive ability.

The cognitive dimension of wisdom is defined as the cognitive ability of the preservice counselors as shown by: meta-cognition, sharpness of views, reasoning and consideration, tolerance of ambiguity, managing uncertainty, open-mindedness, relativism of values, and discovery and problem-solving. Pre-service counselors with meta-cognition skills in the medium category have sufficient knowledge about factual, procedural, and conditional cognition, and are able to manage cognition by planning and evaluating the knowledge of counseling. Pre-service counselors with moderately sensible perspective are quite able to understand counselees and counseling situations in depth, look far beyond the visible, not easily get influenced by counselees' behavior, and offer good and correct alternative solutions for counselees' problems (Ardelt et al., 2019; Hanna et al., 1999).

Pre-service counselors with sufficiently good reasoning ability can recognize the context and interdependence of phenomena, problems, problematic situations, and how to deal with them appropriately; consider every possibility; are rational and logical; and are oriented toward useful therapeutic changes. Pre-service counselors with medium level of judgment or consideration tend to be good at recognizing conflicts in acting and making decisions, thinking deeply before making decisions and acting, and recognizing counselees' independence in making decisions (Hanna \& Ottens, 1995; Moraitou \& Efklides, 2012; Osterlund, 2014).

Pre-service counselors with tolerance for ambiguity tend to feel comfortable enough with ambiguity and love the complexity in counseling and life situations. Pre-service counselors with the ability to manage uncertainty at the medium level are quite able to manage uncertainty in their counseling and life situations. Pre-service counselors with open-mindedness and value relativism in the medium category have good ideas; are happy to try something new; open to diverse ideas, values, and various counseling experiences; and able to appreciate different perspectives so that the counseling processes and outcomes become more optimal. Preservice counselors with moderate discovery and problem-solving skills are characterized, in certain situations and conditions, by being sufficiently able to define, clarify, analyze, choose alternative solutions, and use coping strategies to address the problems faced by themselves and counselees (Hanna \& Ottens, 1995; Hanna et al., 1999).

The religious dimension of wisdom. The scriptures of Islam, Christianity, Judaism, Hinduism, Buddhism, and Confucianism mention that the highest level of one's religiousity is the attainment of wisdom (Marques, 2017). In this research, the religious dimension of wisdom refers to the level of religiosity of pre-service counselors. Pre-service counselors with moderate religious dimension of wisdom have quite strong beliefs in religion and God, sometimes practice religious rituals, have religious altruism, and have sufficient insight on religious issues in counseling.

The reflective dimension of wisdom. Reflective is one of the main dimensions of wisdom. This is in accordance with the opinions of experts and results of previous research findings which show that the dimensions of wisdom include: reflective dimension (Ardelt, 2003), remembering the past, being reflective, and experienced (Webster, 2019), self-reflection (Jeste et al., 2010), and reflective attitudes (Osterlund, 2014).

The reflective dimension of wisdom is the ability of pre-service counselors shown by selfawareness, self-assessment, deautomization, and being rich of experience and learning from mistakes. Pre-service counselors with self-awareness in the medium category are characterized by sufficient awareness of thoughts, feelings, behaviors, and strengths and weaknesses that can affect counseling sessions. Pre-service counselors with moderate self-assessment are characterized by occasional reflection of prior counseling sessions. Preservice counselors with deautomization are

Does The Number of Supervised Counseling Practice Experiences Make Difference in The Wisdom of Pre-Service Counselors? 
inclined to reject automatic behaviors. Preservice counselors with reflective dimension of wisdom in the medium category are also characterized by having enough experience and can sometimes learn from positive and negative experiences, both during counseling and in daily life.

The personal dimension of wisdom. The personal dimension of wisdom is the ability of pre-service counselors to understand, empower, and develop themselves as a unique and dignified person. Pre-service counselors who have personal dimension of wisdom in the medium category are characterized by: (1) having sufficient self-knowledge, in terms of mind, feeling, and behavior; (2) having self-respect; (3) integrating oneself, namely presenting themselves authentically and congruently in various situations; and (4) possessing selfadaptation, i.e., being able to behave and position themselves flexibly and appropriately in front of counselees and in different counseling situations (Brown, 2004; Brown \& Greene, 2006).

Personal dimension is one of the main dimensions of wisdom. This statement is consistent with the opinion of experts and the results of previous research that wisdom is the integration of personality traits (Ardelt, 2018), the virtue of successfully facing integrity crisis againts despair (Erikson, 1959), self-knowledge (Brown, 2004), recognizing the limitations of self-knowledge, having a purpose in life, generativity, ego integrity, self-pity (Jeste et al., 2010), and self-understanding (Meeks \& Jeste, 2009).

Although the present research has proven the hypothesis, there are some limitations. First, the numbers of pre-service counselors with supervised counseling practices experiences $\leq$ $3 x$ and $>3 x$ were not balanced. Second, it did not reveal the model of reflection and supervision used by the counselor educators. Finally, it did not examine differences in the wisdom of the pre-service counselors by sex, ethnicity, age, religious affiliation, life experiences, counseling competencies, and educational institutions. Based on these limitations, further research can carry out the following actions. First, examine, develop, and test the models of reflection and supervision in internships to develop the wisdom of pre-service counselors in counselor education programs. Second, examine the education and training strategies to develop the wisdom of pre-service counselors in counselor education program. Third, examine the differences of the wisdom of the pre-service counselors with a more proportional and representative sample, either in terms of counseling frequencies, gender, ethnicity, age, religious affiliation, life experience, counseling competence, reflection and supervision model, and education institution.

Fourth, "the pedagogical aspects concern competences of counselor educators required for teaching, guiding, and supervising in any academic programs" (Farozin, 2019: 109). Therefore, effective supervision emphasizes the quality of supervisory relationships, commitment to supervision, clarity of duties and procedures, attention to developmental levels, responsibility for evaluation and feedback, clarity of expected outcomes, and methods to evaluate the outcome of supervision.

Therefore, these variables need to be developed and studied further. Fifth, evaluating the process and result as an integral part of learning and supervising process by using multimodal and sources, such as self-report, objective test, case analysis essay test, portfolio, observation, and performance and authentic assessment. The evaluation result became the main materials for self-reflection of pre-service counselors. Finally, because a supervision is a vital component, fundamental intervention, and instrumental pedagogy in counselor education programs. Consequently, a counselor educators or supervisors and site supervisors should continuously supervise the pre-service counselors using various models of supervision such as clinical, administrative, developmental, and integrative through relevant formats such as dyadic, triadic, and group supervision.

\section{CONCLUSION}

This research has confirmed that the hypothesis was accepted, namely there was a significant difference in the wisdom and each dimension (religious, social, emotional, reflective, and affective) of the pre-service counselors based on the number of supervised counseling practice where those with less supervision had better quality of wisdom. This means that the small number of supervised counseling practice experience but with a quality of supervisory working alliance can develop 
the wisdom of pre-service counselors. Further research need to be conducted to examine the quality of the supervisory working alliance between supervisor and supervisee, effect of the supervisee experiences, the competence of the supervisor, and the wisdom of the supervisor on the effectiveness of the models and formats of supervision and the development of wisdom of the supervised pre-service counselors.

\section{REFERENCES}

Aczel, B. (2019). Low levels of wisdom. In R. J. Sternberg, \& J. Glück (Eds.). The Cambridge handbook of wisdom. Cambridge: Cambridge University Press, pp. 483-499.

Ardelt, M. (2003). Empirical assessment of a three-dimensional wisdom scale. Research on Aging, 23(3), 275-324. doi: $10.1177 / 0164027503251764$.

Ardelt, M. (2011). The measurement of wisdom: A commentary on Taylor, Bates, and Webster's comparison of the SAWS and 3D-WS. Journal of Experimental and Aging Research, 37(2), 241-255. doi: 10.1080/0361073X.2011.554509.

Ardelt, M. (2018). Can wisdom and psychosocial growth be learned in university courses. Journal of Moral Education, 7, 1-14, doi: 10.1080/03057240.2018.1471392.

Ardelt, M., Pridgen, S., \& Nutter-Pridgen, K. L. (2019). Wisdom as personality type. In R. J. Sternberg, \& J. Glück (Eds.). The Cambridge handbook of wisdom. Cambridge: Cambridge University Press, pp. 144-161.

ACES. (2011). Association for counselor education and supervision. Alexandria, VA: Autor.

Baltes, P. B., Glück, J., \& Kunzmann, U. (2005). Wisdom: Its structure and function in regulating successful life span. In C. R. Snyder, \& S. J. Lopez (Eds.). Handbook of positive psychology. Oxford: Oxford University Press, pp. 327-347.
Bernard, J. M., \& Goodyear, R. K. (2014). Fundamentals of clinical supervision $\left(5^{\text {th }}\right.$ ed.). Upper Saddle River, NJ: Pearson.

Borders, D. L. (2019). Science of learning: Evidenced-based teaching in the clinical supervision classroom. Counselor Education \& Supervision, 58(1), 64-79. doi:10.1002/ceas.12124.

Bordin, E. S. (1983). A working alliance based model of supervision. Psychotherapy: Theory, Research, and Practice, 16(3),252260. doi:10.1177/0011000083111007.

Brown, S. C. (2004). Learning across the campus: How college facilitates the development of wisdom. Journal of College Student Development, 45(2), 134148. doi:10.1353/csd.2004.0020.

Brown, S. C., \& Greene, J. A. (2006). The wisdom development scale: Translating the conceptual to the concrete. Journal of College Student Development, 47(1), 1-19. doi:2006-01921-001.

Brugman, G. M. (2006). Wisdom and aging. In J. E. Birren, \& K. W. Schaie (Eds.). Handbook of the psychology of aging. Amsterdam: Elsevier, pp. 445-476.

Bruya, B., \& Ardelt, M. (2018). Wisdom can be taught: A proof-of-concept study for fostering wisdom in the classroom. Learning and Instruction, 58(2018), 106-114. doi:10.1016/j. learninstruc.2018.05.001.

Cohen, J. (1988). Statistical power analysis for the behavioural sciences ( $2^{\text {nd }}$ ed.). New York, NY: Lawrence Erlbaum Associates.

CACREP. (2016). Council for Accreditation of Counseling and Related Educational Programs. Alexandria, VA: Autor.

Crits-Christoph, P., Gibbons, M. B., \& Mukherjee, D. (2013). Process-outcome research. In M. J. Lambert (Eds.). Bergin \& Garfield's handbook of psychotherapy 
and behavior change. New York: John Wiley \& Sons, pp. 298-340.

Durodoye, B. A. (2013). Ethical issues in multicultural counseling. In C. L. Courtland, Multicultural issues in counseling (Eds.). Alexandria, VA: American Counseling Association, pp. 295-307.

Erikson, E. H. (1959). Identity and the life cycle. New York, NY: International University Press.

Etezadi, S., \& Pushkar, D. (2013). Why are wise people happier? Journal of Happiness Studies, 14(3), 929-950. doi:10.1007/ s10902-012-9362-2.

Farozin, M. (2019). Counselor professional identity of counselor profession education. Cakrawala Pendidikan, 38(1), 104-119. doi:10.21831/cp.v38i1.22515.

Fluckiger, C., Del Re, A. C., Wampold, B. E., \& Horvath, A. O. (2018). The alliance in adult psychotherapy: A meta-analytic synthesis. Psychotherapy, 55(4), 316-340. doi: $10.1037 /$ pst0000172.

Frantz, G. (2014). Wisdom: Experience or education? Psychological Perspectives, 57(1), 1-3. doi:10.1080/00332925.2014.8 74896.

Glück, J., König, S., Naschenweng, K., Redzanowski, U., Dorner, L., Straßer, I., \& Wiedermann, W. (2013). How to measure wisdom. Frontiers in Psychology, 4(405), 1-13. doi:10.3389/fpsyg.2013.00405.

Granello, D. H., \& Young, M. E. (2012). Counseling today: Foundations of professional identity. Upper Saddle River, NJ: Pearson.

Hanna, F. J., \& Ottens, A. J. (1995). The role of wisdom in psychotherapy. Journal of Psychotherapy Integration, 5(3), 195219. doi:1996-23741-001.

Hanna, F. J., Bemak, F., \& Chung, R. C.-Y. (1999). Toward a new paradigm for multicultural counseling. Journal of Counseling \& Development, 77(2), 125134. doi:10.1002/j.1556-6676.1999. tb02432.x.

Heppner, P. P., Wampold, B. E., \& Kivlighan, D. M. (2008). Research design in counseling. USA: Thomson Brooks/Cole.

Jeste, D. V., Ardelt, M., Blazer, D., Kraemer, H. C., Vaillant, G., \& Meeks, T. W. (2010). Expert consensus on characteristics of wisdom. The Gerontologist, 50(5), 668680. doi:10.1093/geront/gnq022.

Krause, N. (2016). Assessing the relationship among wisdom, humility, and life satisfaction. Journal of Adult Development, 23(3), 140-149. doi:10.1007/s10804-0169230-0.

Kunzmann, U., \& Baltes, P. B. (2005). The psychology of wisdom: Theoretical and empiricl challanges. In R. J. Sternberg, \& J. Jordan (Eds.), A handbook of wisdom: Psychological perspectives. Cambridge: Cambridge University Press, pp. 110-135.

Ladany, N., Mori, Y., \& Mehr, K.E. (2013). Effective and ineffective supervision. The Counseling Psychologist, 41(1), 28-47. doi: 10.1177/0011000012442648.

Levitt, H. M., \& Piazza-Bonin, E. (2016). Wisdom and psychotherapy: Studying expert therapist' clinical wisdom to explicate common process. Psychotherapy Research, 26(1), 31-47, doi:10.1080/1050 3307.2014.937470.

Levitt, H. M., \& Piazza-Bonin, E. (2017). The professionalization and training of psychologists: The place of clinical wisdom. Psychotherapy Research, 27(2), 127-142. doi:10.1080/10503307.2015.1090034.

Linacre, J. M. (2019). A user's guide to Winsteps and Ministep: Rasch-Model computer programs. Winsteps.com.

Marques, J. (2017). A mindful moral compass for twenty-first century leadership. The 
Journal of Values-Based Leadership, 10(1), 1-19. doi:10.22543/0733.101.1177.

Mayer, J. D., Salovey, P., \& Caruso, D. R. (2004). Emotional intelligence: Theory, findings, and implications. Psychological Inquiry, 15(3), 197-215. doi:2004-18872-002.

McAuliffe, G., \& Eriksen, K. (2011). Handbook of counselor preparation. Thousand Oaks, CA: Sage.

Meeks, T. W., \& Jeste, D. V. (2009). Neuroiology of wisdom. Archives of General Psychiatry, 66(4), 355-365. doi:10.1001/ archgenpsychiatry.2009.8.

Milne, D., \& Reiser, R. P. (2012). A rationale for evidence-based clinical supervision. Journal of Contemporary Psychotherapy, 42(3), 139-149. doi:10.1007/s10879-0119199-8.

Moon, J. A. (2004). Handbook of reflective and experiential learning: Theory and practice. London: Routledge Falmer.

Moraitou, D., \& Efklides, A. (2012). The wise thinking and acting questionnaire. Journal of Happiness Studies, 13(1), 849-873. doi:10.1007/s10902-011-9295-1.

Muller-Merbach, H. (2010). Rational versus emotional intelligence plus wisdom. Omega, 38(1), 411-412. doi:10.1016/j. omega.2010.04.001.

Osbeck, R. M., \& Robinson, D. N. (2005). Philosophical theories of wisdom. In R. J. Sternberg, \& J. Jordan (Eds.). A handbook of wisdom: Psychological perspectives. Cambridge: Cambridge University Press, pp. 61-83.

Osterlund, L. C. (2014). Wisdom in the helping relationship. Jesuit Higher Education, 3(2), 74-84. https://epublications.regis. edu/jhe.

Osterlund, L. C. (2016). Developing wisdom in counselors of the future: Ignatian pedagogy applied to counselor education and supervision. VISTAS Online, 2016(Article 35), 1-11. https://www.counseling.org.

Phan, L. T., Torres-Rivera, E., Volker, M., \& Maddux, C. D. (2009). Wisdom in multicultural counseling: In omitted ingredient. Interamercan Journal of Psychology, 43(1), 154-161.

Schoon, D. (1987). Educating reflective practitioner. San Fransisco, CA: Jossey-Bass.

Sternberg, R. J. (2013). Reform education: Teach wisdom and ethics. Phi Delta Kappan, 94(7), 44-47. doi:10.1177/003172171309400715.

Sternberg, R. J., \& Hagen, E. S. (2019). Teaching for wisdom. In R. J. Sternberg, \& J. Glück (Eds.). The Cambridge handbook of wisdom. Cambridge: Cambridge University Press, pp. 372-406.

Tan, S. Y. (2017). Clinical group supervision experiences of Singapore school counsellors. British Journal of Guidance \& Counselling, 47(4), 1-14. doi:10.1080/ 03069885.2017 .1371275 .

Webster, J. D. (2019). Self-report wisdom measures: Strengths, limitations, and future directions. In R. J. Sternberg, \& J. Glück (Eds.). The Cambridge handbook of wisdom. Cambridge: Cambridge University Press, pp. 297-320.

Webster, J. D., Westerhof, G. J., \& Bohlmeijer, E. T. (2014). Wisdom and mental health across the life span. Journal of Gerontology: Series B, Psychological Sciences and Social Sciences, 69(2), 209218. doi: 10.1093/geronb/gbs121.

Yang, S.-Y. (2013). Wisdom and good lives: A process perpective. New Ideas in Psychology, 31(1), 194-201. doi:10.1016/2013.03.001.

Zacher, H., \& Staudinger, U. M. (2018). Wisdom and well-being. In E. Diener, S. Oishi, \& L. Tay (Eds.). Handbook of well-being. Salt Lake City: DEF Publishers, pp. 604-617. 